\title{
FECAL SPECIMENS PREPARATION METHODS FOR PCR DIAGNOSIS OF HUMAN TAENIOSIS
}

Cáris Maroni NUNES, Luiz Gustavo Ferraz LIMA, Camila Santos MANOEL, Rodrigo Norberto PEREIRA, Mauro Massaharu NAKANO \& José Fernando GARCIA

\section{SUMMARY}

Sample preparation and DNA extraction protocols for DNA amplification by PCR, which can be applied in human fecal samples for taeniasis diagnosis, are described. DNA extracted from fecal specimens with phenol/chloroform/isoamilic alcohol and DNAzol ${ }^{\circledR}$ reagent had to be first purified to generate fragments of $170 \mathrm{pb}$ and $600 \mathrm{pb}$ by HDP2-PCR. This purification step was not necessary with the use of QIAmp DNA stool mini kit ${ }^{\circledR}$. Best DNA extraction results were achieved after eggs disruption with glass beads, either with phenol/chloroform/isoamilic alcohol, DNAzol ${ }^{\circledR}$ reagent or QIAmp DNA stool mini kit ${ }^{\circledR}$.

KEYWORDS: Taenia saginata; DNA extraction; Polymerase chain reaction (PCR); Fecal specimens.

\section{INTRODUCTION}

Taeniosis and cysticercosis are important public health and economic problems through the world. Taenia solium and Taenia saginata are the two taeniids responsible for taeniosis in man and swine and bovine cysticercosis, respectively. T. solium eggs can also infect man and cause neurocysticercosis ${ }^{4}$. Humans are responsible for dispersion of the parasite's eggs in the environment through outdoor defecation and indiscriminate disposal of feces ${ }^{13}$.

The detection of human carriers is one of the keys for the implementation of control programmes for these diseases. Classically, differentiation between $T$. solium and $T$. saginata is based on the morphological aspects of mature proglottides in feces and lacks sensibility because of the intermittent nature of egg excretion ${ }^{2}$. Although immunodiagnosis based in coproantigen detection by enzyme-linked immunosorbent assay (ELISA) has improved sensitivity, the two species cannot be distinguished ${ }^{1,4}$. Polymerase chain reaction (PCR) with oligonucleotide primers derived from specie-specific probes is a sensitive and specific diagnostic method ${ }^{3,5,7,11}$. PCR for DNA parasite detection in fecal specimens can lack sensitivity because of difficulties on liberating DNA from eggs and the presence of PCR inhibitors ${ }^{8,10,14}$. Efficient DNA extraction protocol from fecal specimens has to deal with these issues.

In this article we describe our attempts to improve sample preparation and DNA extraction from fecal specimens for Taenia saginata DNA amplification by PCR.

\section{MATERIAL AND METHODS}

Taenia saginata proglottids and fecal samples were obtained from a naturally infected patient after informed consent and approval from the local ethic committee. Initially, thirteen DNA extraction protocols were evaluated and the essentials for each one are briefly described on Table 1. The QIAmp DNA extraction stool minikit ${ }^{\circledR}$ (Quiagen, Helden, Germany) protocol, also shown on Table 1, was tested latter once it was not available at the time we started our experiment. All protocols were tested using $2 \mathrm{~g}$ of sediment from the same positive fecal sample, performed in duplicates and the final elution volume was $100 \mu \mathrm{L}$, in TE buffer or as the suppliers' instructions.

With the exception of the samples submitted to QIAmp DNA extraction stool minikit ${ }^{\circledR}$, all the other samples were submitted to a second round of DNA purification using the PCR QIAquick ${ }^{\circledR}$ system (Quiagen, Helden, Germany) and dilution in water (1:2), prior to PCR. The final DNA volume was $30 \mu \mathrm{L}$.

HDP2-PCR was performed with oligonucleotide primers described previously by GONZÁLEZ et al. ${ }^{3}$, with slight modifications, and the protocol is described elsewhere ${ }^{9}$. As mentioned by NUNES et al. ${ }^{9}$, better results were observed when two separated PCR were performed instead of the multiplex PCR described by GONZÁLEZ et al. ${ }^{3}$, resulting in amplification of 600 bp DNA fragment specific for T. saginata and 170bp DNA fragment, specific for both T. saginata and T. solium. Each sample was tested at least twice, in duplicate and results were the same. As reaction controls, DNA from T. solium metacestode obtained 


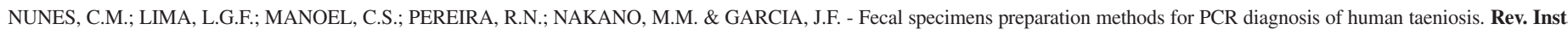
Med. trop. S. Paulo, 48(1): 45-47, 2006.

Table 1

General summary of fecal sample treatment and DNA extraction protocols for HDP2-PCR.

\begin{tabular}{|c|c|c|c|c|c|c|c|c|c|c|c|c|c|c|}
\hline \multirow[b]{2}{*}{ Protocol steps } & \multicolumn{14}{|c|}{ Samples } \\
\hline & F1 & $\mathrm{F} 2$ & F3 & F4 & F5 & F6 & F7 & F8 & F9 & F10 & F11 & F12 & F13 & F14 \\
\hline $\begin{array}{l}\text { Shaking with glass beads, } 20 \mathrm{~min} \\
\text { ( } 50 \text { units, } 0.4 \mathrm{~cm} \text { diameter). }\end{array}$ & & $\mathrm{x}$ & & $\mathrm{x}$ & $\mathrm{x}$ & $\mathrm{x}$ & & & & $\mathrm{x}$ & $\mathrm{x}$ & $\mathrm{x}$ & $\mathrm{x}$ & $\mathrm{x}$ \\
\hline $\begin{array}{l}\text { Proteinase } \mathrm{K}(1 \mathrm{mg}) \text { at } 56^{\circ} \mathrm{C} \text {, } \\
2 \text { hours }\end{array}$ & $\mathrm{x}$ & $\mathrm{x}$ & $\mathrm{x}$ & $2 \mathrm{x}$ & $\mathrm{x}$ & $2 \mathrm{x}$ & & $\mathrm{x}$ & $\mathrm{x}$ & & $\mathrm{x}$ & & & \\
\hline Water-ether sedimentation & & $\mathrm{x}$ & $\mathrm{x}$ & $\mathrm{x}$ & & & & & & & & & & \\
\hline $\begin{array}{l}\text { Sodium hipochloride } 5 \%, 10 \mathrm{~min} \text {. } \\
\text { before shaking with glass beads }\end{array}$ & & & & $\mathrm{x}$ & & $\mathrm{x}$ & & & & & & & $\mathrm{x}$ & \\
\hline $\begin{array}{l}\text { Centrifuge-flotation with sodium } \\
\text { dichromate }(\mathrm{d}=1035)\end{array}$ & & & & & & & & & & & $\mathrm{x}$ & & & \\
\hline $\begin{array}{l}\mathrm{KOH} 1 \mathrm{M}, \mathrm{DTT} 1 \mathrm{M} \text {, at } 65^{\circ} \mathrm{C} \text {, } \\
15 \mathrm{~min}\end{array}$ & & & & & & & $\mathrm{x}$ & & & & & & & \\
\hline $\begin{array}{l}\text { Tween } 20^{\circledR} 0.1 \% \text { before shaking } \\
\text { with glass beads }\end{array}$ & & & & & & $\mathrm{x}$ & & & & & & & & \\
\hline Freeze and -thawing $(5 \mathrm{x})$ & & & & & & & & & $\mathrm{x}$ & & & & & \\
\hline $\begin{array}{l}\text { GFX genomic blood kit } \\
\text { (Amersham Biotech) }\end{array}$ & $\mathrm{x}$ & & & & & & & & & & & & & \\
\hline $\begin{array}{l}\text { Phenol/chloroform/isoamilic } \\
\text { alcohol and ethanol precipitation }{ }^{12}\end{array}$ & & $\mathrm{x}$ & $\mathrm{x}$ & $\mathrm{x}$ & $2 \mathrm{x}$ & $\mathrm{x}$ & $\mathrm{x}$ & & & & $3 x$ & & & \\
\hline $\begin{array}{l}\text { Nucleospin tissue kit }{ }^{\circledR} \\
\text { (Macherey-Nagel) }\end{array}$ & & & & & & & & $\mathrm{x}$ & & & & & & \\
\hline $\mathrm{NaCl} 5 \mathrm{M}$ & & & & & & & & & $\mathrm{x}$ & & & & & \\
\hline $\begin{array}{l}2 \mathrm{~mL} \text { DNAzol }{ }^{\circledR} \text { reagent } \\
\text { (Invitrogen) }\end{array}$ & & & & & & & & & & $\mathrm{x}$ & & $\mathrm{x}^{*}$ & $\mathrm{x}$ & \\
\hline $\begin{array}{l}\text { QIAmpDNA stool minikit } \\
\text { (Quiagen) }\end{array}$ & & & & & & & & & & & & & & $\mathrm{x}$ \\
\hline
\end{tabular}

$\mathrm{x}=$ one time treatment; $2 \mathrm{x}=$ two times; $3 \mathrm{x}=$ three times; $*$ at $85^{\circ} \mathrm{C}, 25 \mathrm{~min}$.

by phenol extraction and ethanol precipitation ${ }^{12}$, DNA from a positive fecal sample obtained by DNAzol ${ }^{\circledR}$ reagent (Invitrogen, Carlsbad, California) and a negative control (no DNA) were included.

\section{RESULTS AND DISCUSSION}

The PCR-based methodology available can be performed in order to differentiate T. solium and T. saginata eggs in fecal specimens ${ }^{9}$ and it is important to keep in mind that sample preparation and DNA extraction methods influence the outcome and reliability of the test ${ }^{6}$. In the present paper, we have compared several sample preparation and DNA extraction protocols using fecal samples containing Taenia saginata eggs for PCR.

All the thirteen protocols initially tested did not result in DNA amplification by PCR unless DNA was submitted to a second round of purification (PCR QIAquick ${ }^{\circledR}$ system). Also, PCR was performed with undiluted (data not shown) and 1:2 diluted DNA and the best results were observed with diluted DNA, which could indicate that inhibitors present in the fecal samples were being diluted ${ }^{8,10,14}$.

Taenia DNA is contained in walled egg that makes extraction more difficult. For egg disruption we have compared shaking with glass beads (Fig. 1 F2, F4, F5, F6, F10, F11, F12 and F13), alkaline treatment
(Fig. 1 F7) and freeze thawing (Fig. 1 F9). Previous shaking with glass beads gave best results either with phenol/chloroform/isoamilic alcohol (Fig. 1 F2, F4, F6 and F11), DNAzol ${ }^{\circledR}$ reagent (Fig. 1 F10, F12 and

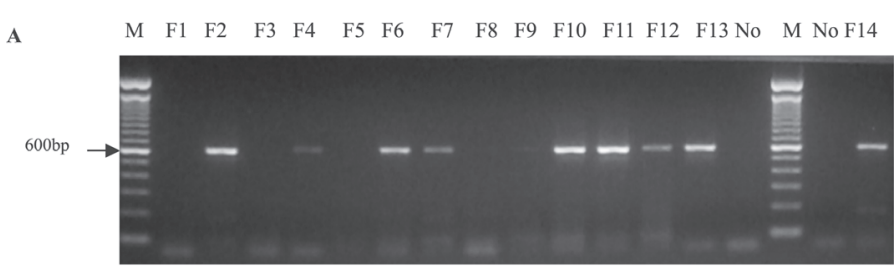

B $\begin{array}{llllllllllllllllllllll}\text { M } & \text { F1 } & \text { F2 } & \text { F3 } & \text { F4 } & \text { F5 } & \text { F6 } & \text { F7 } & \text { F8 } & \text { F9 } & \text { F10 } & \text { F11 } & \text { F12 } & \text { F13 } & \text { No } & \text { No } & \text { M } & \text { F14 }\end{array}$

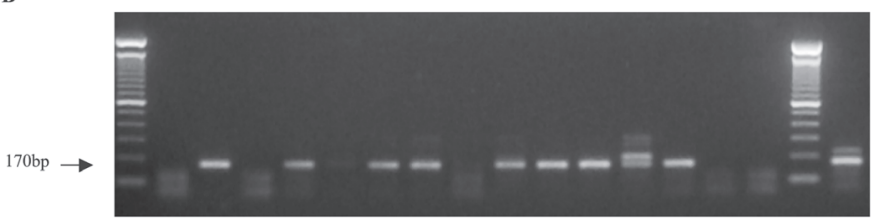

Fig. 1 - Agarose gel electrophoresis (2\%) ethidium bromide stained, from PCR fragments using primers PTs7S35F1 and PTs7S35R1 (A) and PTs7S35F2 and PTs7S35R1(B). Fecal sample DNA extraction protocols (see Table 1) - no DNA (No). 100 base pairs ladder molecular marker (M). 
F13) or even with the QIAmp DNA stool mini kit ${ }^{\circledR}$ (data not shown) as DNA extraction protocol.

Phenol/chloroform/isoamilic alcohol (PCI) protocol showed good results (Fig. 1 F2, F6, F7 and F11) and, although cheaper than commercial kits, it is time consuming, besides hazardous. Extraction with DNAzol reagent ${ }^{\circledR}$ also resulted in DNA amplification by PCR (Fig. 1 F10, F12 and F13) and it is easier and faster to perform than PCI.

Best results were observed with the of QIAmp DNA stool mini kit $^{\circledR}$ (Fig. 1 F14) with or without previous shaking with glass beads. Since we had to use one purification step after DNA extraction while using PCI or DNAzol reagent ${ }^{\circledR}$, costs will be about the same with the QIAmp DNA stool mini kit ${ }^{\circledR}$ which is easier and faster to perform and it eliminates the inhibitors present in fecal specimens at one time.

This report aimed at describing our attempts to improve fecal specimens preparation in order to achieve Taenia saginata DNA amplification by PCR. Depending on time and costs, one can decide whether to use one or another protocol. We strongly recommend shaking with glass beads before any method for $T$. saginata DNA extraction from fecal specimens.

\section{RESUMO}

\section{Métodos de preparação de amostras de fezes para diagnóstico de teníase humana através da PCR}

Com o intuito de utilizar a Reação em Cadeia pela Polimerase (PCR) como método de diagnóstico diferencial da teníase humana, avaliaram-se alguns protocolos de preparação e extração de DNA de ovos de Taenia saginata presentes em amostras de fezes de paciente naturalmente infectado. O DNA obtido após extração com fenol/ clorofórmio/álcool isoamílico ou DNAzol ${ }^{\circledR}$ teve que ser purificado antes da PCR para que fosse possível a amplificação dos fragmentos de 170 pb e 600 pb desejados. Com o kit QIAmp DNA stool mini kit ${ }^{\circledR}$ tal purificação não foi necessária. Os melhores resultados foram observados após o tratamento prévio das amostras com pérolas de vidro, tanto quando da utilização de fenol/clorofórmio/álcool isoamílico, quando de DNAzol ${ }^{\circledR}$ ou QIAmp DNA stool mini kit ${ }^{\circledR}$.

\section{ACKNOWLEDGMENTS}

The authors are grateful to Dr. Germano Francisco Biondi, Ana Karina Kerche Dias, Pedro Luis Florindo, Henrique Borges de Paula and Fernanda Patrícia Gottardi for their collaboration. This research was conducted with support of FAPESP (2000/10183-5).

\section{REFERENCES}

1. ALlAN, J.C.; AVILA, G.; GARCIA NOVAL, J.; FLISSSER, A. \& CRAIG, P.S. Immunodiagnosis of taeniasis by coproantigen detection. Parasitology, 101: 473 477, 1990.

2. ALLAN, J.C.; WILKINS, P.P.; TSANG V.C.W. \& CRAIG, P.S. - Immunodiagnostic tools for taeniasis. Acta trop., 87: 87-93, 2003.

3. GONZÁLEZ, L.M.; MONTEIRO, E.; HARRISON, L.J.S.; PARKHOUSE, R.M.E. \& GARATE, T. - Differential diagnosis of Taenia saginata and Taenia solium infection by PCR. J. clin. Microbiol., 38: 734-744, 2000.

4. GONZÁLEZ, L.M.; MONTERO, E.; PUENTE, S. et al. - PCR tools for the differential diagnosis of Taenia saginata and Taenia solium taeniasis/cysticercosis from different geographical locations. Diagn. Microbiol. infect. Dis., 42: 243-249, 2002.

5. GOTTSTEIN, B.; DEPLAZES, P.; TANNER I. \& SKAGGS, J.S. - Diagnostic identification of Taenia saginata with the polymerase chain reaction. Trans. roy. Soc. trop. Med. Hyg., 85: 248-249, 1991.

6. LACHAUD, L.; CHABBERT, E.; DUBESSAY, P. et al. - Comparison of various sample preparation methods for PCR diagnosis of visceral leishmaniasis using peripheral blood. J. clin. Microbiol., 39: 613-617, 2001.

7. McMANUS, D.P.; GARCIA-ZEPEDA E.; REID, A.; RISHI, A.K. \& FLISSER, A. Human cysticercosis and taeniasis: molecular approaches for specific diagnosis and parasite identification. Acta leidensia, 57: 81-91, 1989.

8. MULLER, A.; STELLERMANN, K.; HARTMANN, P. et al. - A powerful DNA extraction method and PCR for detection of microsporidia in clinical stool specimens. Clin. diagn. Lab. Immunol., 6: 243-246, 1999.

9. NUNES, C.M.; LIMA, L.G.F.; MANOEL, C.S. et al. - Taenia saginata: polymerase chain reaction for taeniasis diagnosis in human fecal samples. Exp. Parasit., 104: 67-69, 2003.

10. ORLANDI, P.A. \& LAMPEL, K.A. - Extraction-free, filter-based template preparation for rapid sensitive PCR detection of pathogenic parasite protozoa. J. clin. Microbiol., 38: 2271-2277, 2000 .

11. RODRIGUEZ-HIDALGO, R.; GEYSEN, D.; BENITEZ-ORTIZ, W.; GEERTS, S. \& BRANDT, J. - Comparison of conventional techniques to differentiate between Taenia solium and Taenia saginata and an improved polymerase chain reaction-restriction fragment lenght polymorphism assay using a mitochondrial 12S rDNA fragment. J. Parasit., 88: 1007-1011, 2002.

12. SAMBROOK, J.; FRITSCH, E.F. \& MANIATIS, T. - Molecular cloning: a laboratory manual. 3. ed. New York, Cold Spring Harbor Press, 1989.

13. SARTI, E. \& RAJSHEKHAR, V. - Measures for the prevention and control of Taenia solium taeniosis and cysticercosis. Acta trop., 87: 137-143, 2003.

14. SILVA, A.J.; BORNAY-LINARES, F.J.; MOURA, I.N.S. et al. - Fast and reliable extraction of protozoan parasite DNA from fecal specimens. Molec. Diagn., 4: 57-64, 1999.

Received: 10 September 2004

Accepted: 10 November 2005 